$$
\begin{aligned}
& \text { アルミニウム合金製自動車エンジンブロックの残留応力 }{ }^{\dagger}
\end{aligned}
$$

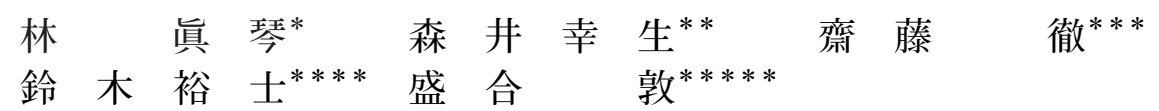

\title{
Residual Stress Measurement in Aluminum Engine Block
}

by

\author{
Makoto HayaShI $^{*}$, Yukio MorII ${ }^{* *}$, Toru SAITo ${ }^{* * *}$, Hiroshi SuZUKI ${ }^{* * * *}$ and Atsushi MorIAI ${ }^{* * * * *}$
}

Residual stress distribution at the cylinder block wall in 1500cc class aluminum engine was measured using RESA in JRR-3 of JAEA. In order to increase neutron flux at the gauge volume measured, newly developed vertically focused collimator was employed. Since the grain size in cast aluminum engine block was large, the oscillation method was applied. The residual stresses near the surface layers of cylinder block wall were compressive all in the tangential, the thickness and the cylinder axial directions, but tensile in the middle part of cylinder block wall. This means the residual stress distributions are likely to be hydrostatic. The residual stresses in the tangential direction were not balanced in the cylinder block wall. If the residual stress distribution in the hoop direction is approximated by 2 dimensional power equation, the residual stresses on the cylinder wall surface is estimated as about $-140 \mathrm{MPa}$ and the mean residual stress in the cylinder wall is $15 \mathrm{MPa}$.

Key words : Residual stress, Neutron diffraction, Aluminum engine, Coarse grain, Oscillation method

\section{1 緒}

\section{言}

機械構造物や部品の強度信頼性に影響を及ぼす重要な 因子として, 溶接や機械加工，熱処理，鋳造などによる 残留応力がある. 強度に影響を及ぼす残留応力は主とし て材料表面の残留応力であり，従来は表面の応力測定に

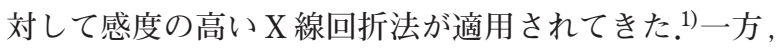
例えば，高温ガスタービンでは，耐熱性を向上させるため に熱遮へいコーティングを施すが，その界面からき裂が発 生することがある。皇机に対してコーティングを施工した ときに発生する残留応力が影響すると指摘されている。. コーティング層の厚さは高々数十 $\mu \mathrm{m}$ であるが, ラボ X 線では侵入深さが浅いためにコーティング層界面近傍の 応力を測定することができない，穴のため，エネルギーの 高い放射光 X線が適用されている. 高いエネルギーの放 射光を用いると鋼でも深さ $1.5 \mathrm{~mm}$ 内部の残留応力を測 定することが可能で，ひずみスキャニング法が開発され ている.3)

中性子はラボ $\mathrm{X}$ 線や放射光と比較して侵入深さが極め て大きいのが特徴である。この特性を活かしてソケット 継手溶接部や厚板溶接部内部の残留応力が測定されてい る.4) 6)アルミニウムの場合, 侵入深さが $1,200 \mathrm{~mm} に も$ 達するため, 最近では自動車エンジン部品の組立て応力 の評価やエンジンブロック周りの鋳造残留応力の評価に
適用する試みもなされている。

自動車は燃費改善のためにさまざまな取組みがなされ ている，その 1 つが車体の軽量化である，その中でもエ ンジンの小型軽量化は大きい効果を有する。エンジンの 小型化のためには, エンジンブロックの大きさを $1 \mathrm{~mm} て ゙$ も縮小することが重要である。午の場合, 最も強度信頼 性上重要となるのはシリンダヘッドやシリンダブロック 内部の残留応力である. エンジンブロック内部の残留応 力測定に抢いては 2 つの問題点がある. 1 つはエンジン ブロックが全長数百 $\mathrm{mm}$ もあるため, 従来の中性子入射 ビームスリットではゲージ体積が大きくなってしまうこ とである，このため，本研究では入射ビームを縦方向に 収束させるラジアルコリメータスリットを開発した．2つ 目は，アルミニウムエンジンは鋳造されるため結晶粒が 粗大で, かつ, 集合組織が強いことが予想され，回折に 預かる結晶粒を多くするために試料を摇動させたとして も十分な回折強度を得ることができず, 高い精度での応 力が期待できないことである。爷こで本研究では，アル ミニウム合金製のエンジンブロックの中性子回折による 残留応力測定技術の確立を目的として，1,500cc 級エン ジンブロックを用いて測定精度に及ぼす摇動の影響につ いても検討した.

\footnotetext{
$\dagger \quad$ 原稿受理 平成 22 年 10 月 8 日 $\quad$ Received Oct. 8, 2010 @ 2011 The Society of Materials Science, Japan

* 正 会員 茨城県企画部 干319-1106 茨城県那珂郡東海村白方, Planning Div., Ibaraki Prefecture, Naka-gun, Ibaraki, 319-1106

** ひたちなかテクノセンター ７319-1106 茨城県那珂郡東海村白方, Hitachi-Naka Techno Center, Naka-gun, Ibaraki, 319-1106

**** 正 会員 神戸工業試験場 †319-1231 日立市留町, Kobe Materials Testing Lab., Tome-cho, Hitachi, 319-1231

**** 正会員 日本原子力研究開発機構 =319-1195 茨城県那珂郡東海村白方白根, Japan Atomic Energy Agency, Naka-gun, Ibaraki, 319-1195

$* * * * *$ 日本原子力研究開発機構 $=319-1195$ 茨城県那珂郡東海村白方白根, Japan Atomic Energy Agency, Naka-gun, Ibaraki, 319-1195
} 


\section{2 実 験 方 法}

日本原子力研究開発機構の研究用原子炉 JRR-3 の残留 応力測定装置 RESA-1 ではベント型非対称モノクロメー タにより単色化した入射ビームを最終的には矩形形状の Cd スリットでゲージ体積を設定している．しかし，この 方法ではスリットから収束点までの距離 L1 が長いと, Fig. 1 上図に示すように入射ビームの発散により, 試料 位置におけるビーム高さはスリットサイズに比べて大き く広がり, 中性子束密度が低下するという問題がある. 本研究の対象である, アルミニウム合金製のエンジンブ ロックは結晶粒径 $0.1 \mathrm{~mm}$ オーダーで, 一般構造用炭素 鋼の $20 \mu \mathrm{m}$ 程度と比較すると数倍大きいため, 通常の測 定法では精度よく残留応力を測定することができない. そこで，新しく入射中性子ビーム強度を低下させること なく，スリットー試料間距離を大きく取れる鉛直面内集 光型のラジアルコリメータを世界で初めて開発した. Fig. 1 下部にその構造概念図を示す。両面に中性子吸収材であ る $\mathrm{Gd}_{2} \mathrm{O}_{3}$ を塗布した厚さ $30 \mu \mathrm{m}$ の 2 軸延伸ポリエチレン テレフタレート (PET) フィルムを試料位置に向かって収 束するように扇の栈状に配置し, 中性子の入射方向を絞っ て試料位置におけるビーム高さを所定のサイズに集光す るというものである. ラジアルコリメータの設計として は，1）収束距離を $500 \mathrm{~mm} ， 2 ）$ ひずみ測定位置における ビーム高さを $5 \mathrm{~mm} ， 3)$ ラジアルコリメータの全長は約 $400 \mathrm{~mm}$ ，4）収束ラジアルコリメータの分割数は $10 \mathrm{ch}$ と した.

この考えに基づいて設計，製作した入射スリットの断 面構造を Fig. 2 に示す. スリットの全長は $384 \mathrm{~mm}$ ，入 り口側の幅は $44.146 \mathrm{~mm}$ で，コリメータの間隔は $4.36 \mathrm{~mm}$ である. 出口側の幅は $24.99 \mathrm{~mm}$ で, コリメータ の間隔は $2.444 \mathrm{~mm}$ である.

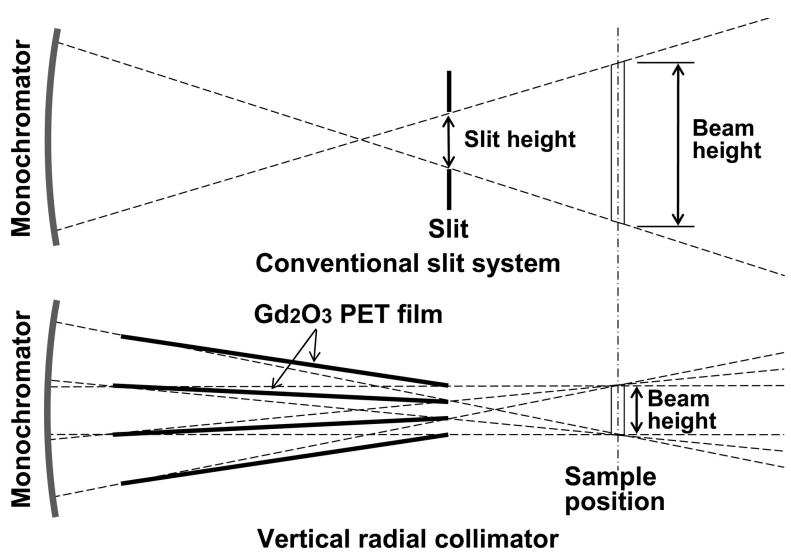

Fig. 1 Concept of vertical radial collimator.

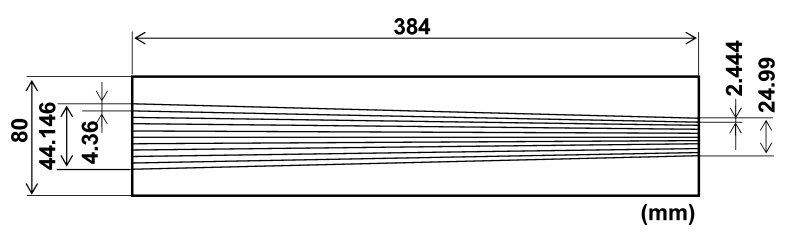

Fig. 2 Cross section of vertical radial collimator for incident neutron beam.
Fig. 3 に開発した縦収束ラジアルコリメータを用いて 測定した距離 L1 を変えたときのビーム強度を示す。設 計点 $\mathrm{L} 1=500 \mathrm{~mm}$ に打いてビーム強度が最大となってい ることが分かる.

Fig. 4 には距離 L1 を変えたときのビーム形状を中性 子イメージングプレート (NIP) を用いて測定した結果を 示す. $\mathrm{L} 1=500 \mathrm{~mm}$ においてビーム高さの半值幅 $\mathrm{H}_{\mathrm{FWHM}}$ が $5 \mathrm{~mm}$ と最小值を示すとともに，設計值通りとなって いることが分かる.

検出器には受光面積が $100 \mathrm{~mm} \times 100 \mathrm{~mm}$ の韓国原子 力研究所 (KAERI) 製の一次元検出器を用い, 検出器の 前方にはラジアルコリメータを配置した。測定対象であ るアルミニウム合金製エンジンブロックは粗大結晶粒で あるため，エンジンブロックを $2 \theta$ 方向に最大で $\pm 5 \mathrm{deg}$ 摇動させた。具体的には $\omega=-5 \mathrm{deg}$ から $\omega=+5 \mathrm{deg}$ まで $\Delta \omega=0.5 \mathrm{deg}$ 間隔で回折プロフィルを測定し, 摇動角度 範囲に応じて積分した。

無ひずみ状態の格子定数 $\mathrm{d}_{0}$ は，エンジンブロックから 約 2cc ヤスリで削った粉末にひずみ取り焼鈍 (SR) とし て $200^{\circ} \mathrm{C} \times 30 \mathrm{~min}$ の熱処理を施したもので測定した.

ゲージ体積は縦収束コリメータの出口に幅方向スリッ

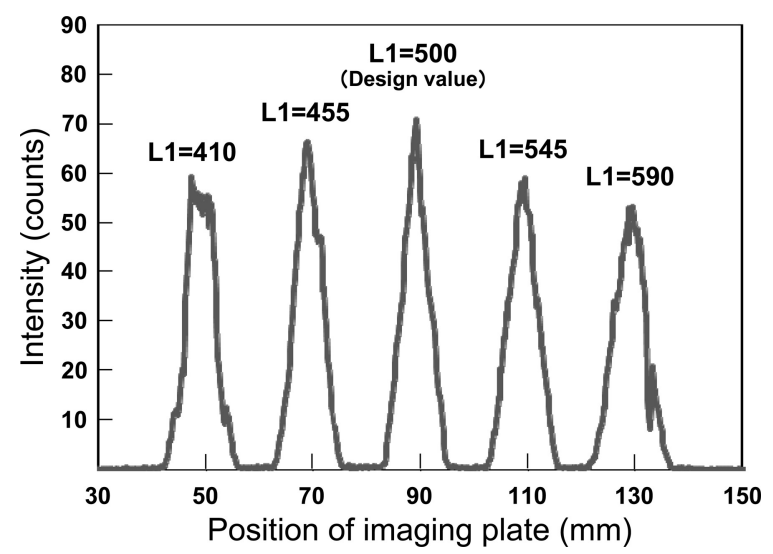

Fig. 3 Incident beam intensity change for distance L1 between collimator and gauge volume.
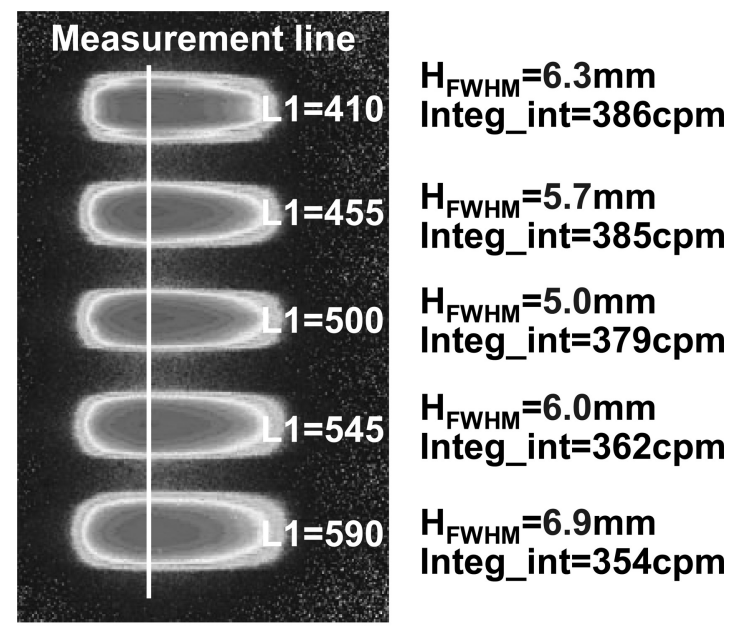

\section{NIP image measured}

Fig. 4 Configuration of incident neutron beam squeezed by vertical radial collimator. 
トを設けることにより $\mathrm{r} ， \theta$ 方向ひずみ測定では $2 \times 2 \times$ $5 \mathrm{~mm}^{3}$ とした。このときの波長は $\lambda=0.17307 \mathrm{~nm}$ である. また,$Z$ ひずみ方向ひずみ測定では $2.6 \times 2.6 \times 2.4 \mathrm{~mm}^{3}$ とした。このときの波長は $\lambda=0.17304 \mathrm{~nm}$ である.

エンジンを小型化するためにはシリンダブロック隔壁 を薄くすることが必要である。そのため，シリンダ隔壁 における残留応力分布を測定した. 測定状況を Fig. 5 に 示す，入射ビームスリットの先端にあるのが縦収束ラジ アルコリメータである。縦収束コリメータを用いたため, コリメータ先端からエンジンブロックまでは十分な空間 を確保することができ, 従来のように，2 軸方向のひず みを測定するために, 入射ビームスリット位置を動かし て再設定する必要がなくなり，2 軸方向のひずみを連続 して測定できるようになった。

シリンダ隔壁における測定位置とゲージ形状を Fig. 6 に示す。本研究では全長が約 $500 \mathrm{~m}$ の 1,500cc 級エンジ ンブロックの中央のシリンダ隔壁を対象とした。困中に示 したように座標系としては，シリンダを基準とし，エンジ ンのクランク軸方向を $\mathrm{r}$ ，ピストン方向を $\mathrm{z}$ ，シリンダの 周方向を $\theta$ とした. シリンダ隔壁の厚さは $\mathrm{t}=8.2 \mathrm{~mm}$ で ある。ゲージ幅が $2 \mathrm{~mm}$ であるため厚さ方向で 5 箇所測 定した．測定中心はシリンダ表面から $\mathrm{r}=1 ， 2.6 ， 4.1$, 5.6，7.2mm である。なお，ゲージ体積が測定試料から

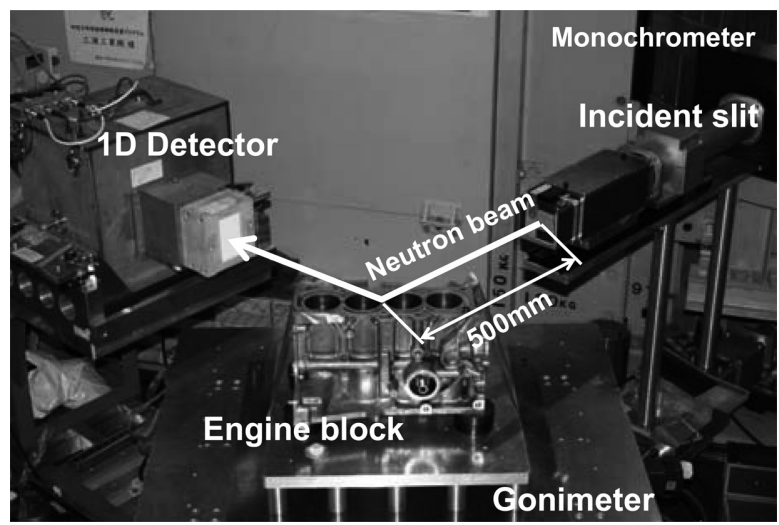

Fig. 5 Appearance of residual stress measurement in aluminum engine block at RESA-1 of JRR-3.

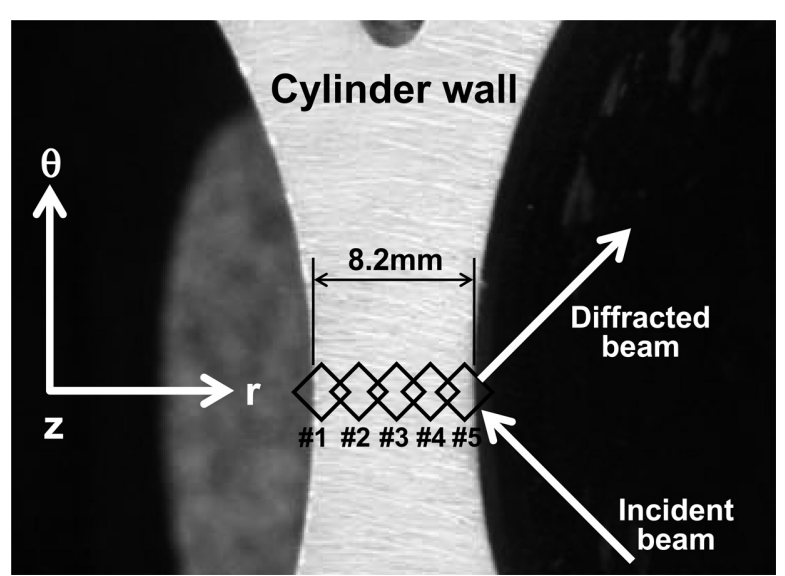

Fig. 6 Strain measurement area in $r, \theta$ directions in cylinder wall.
外れた場合には見かけのピークシフトが生じることがあ るが，Fig. 6 に示したように，表面に近い測定点におい てゲージ体積から外れる試料体積は小さいこと，また， 回折角度が $2 \theta=90 \mathrm{deg}$ に近いために見かけのピークシ フトは小さいものとして評価した。

参考のためにシリンダブロックの金属組織写真を Fig. 7 に示す。平均結晶粒径は約 $15 \mu \mathrm{m}$ である，前述したよう にRESA-2 での予備測定では回折強度が得られず，結晶 粒径が大きいものと推定していたが，図に示すように結 晶粒はアルミニウム鋳造材としてはむしろ小さい。これ は，シリンダ隔壁は鋳造時に中子に挟まれているために 冷却速度が速く，結晶粒径が小さくなったものと推定さ れる。

\section{3 実 験 結 果}

無ひずみ状態の格子定数 $\mathrm{d}_{0}$ を測定した $\mathrm{SR}$ 処理を施し たヤスリ掛け粉末の 311 回折プロフィルを Fig. 8 に示す. 回折ピーク位置は $2 \theta_{0}=90.3601 \mathrm{deg}$ であり，半值幅は $\mathrm{FWHM}=0.450 \mathrm{deg}$ である. この回折ピークから無ひずみ 状態の $\mathrm{d}_{0}$ は $0.1219856 \mathrm{~nm}$ で, 格子定数は $\mathrm{a}_{0}=0.40458 \mathrm{~nm}$ となる.

エンジンブロック隔壁の表面から $\mathrm{r}=2.6 \mathrm{~mm}$ （測定位 置＃2）で測定した回折プロフィルを Fig. 9 に示す.ダ ブルピークが得られており，測定対象の 311 回折以外に，

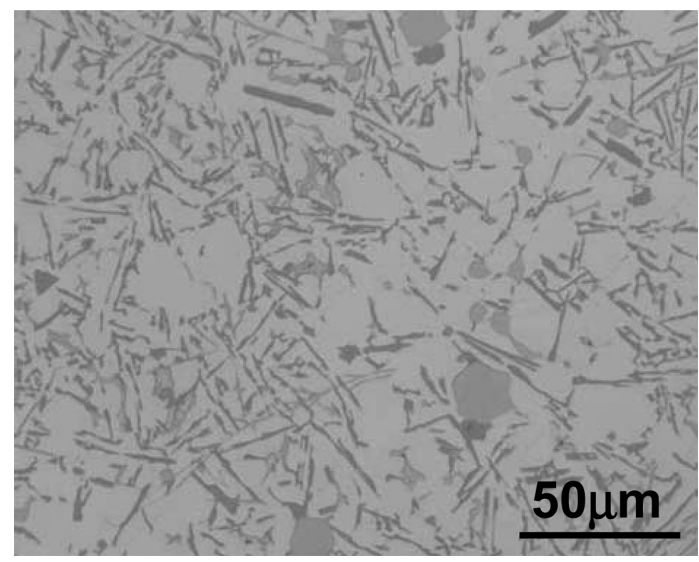

Fig. 7 Micro-structure of engine cylinder block.

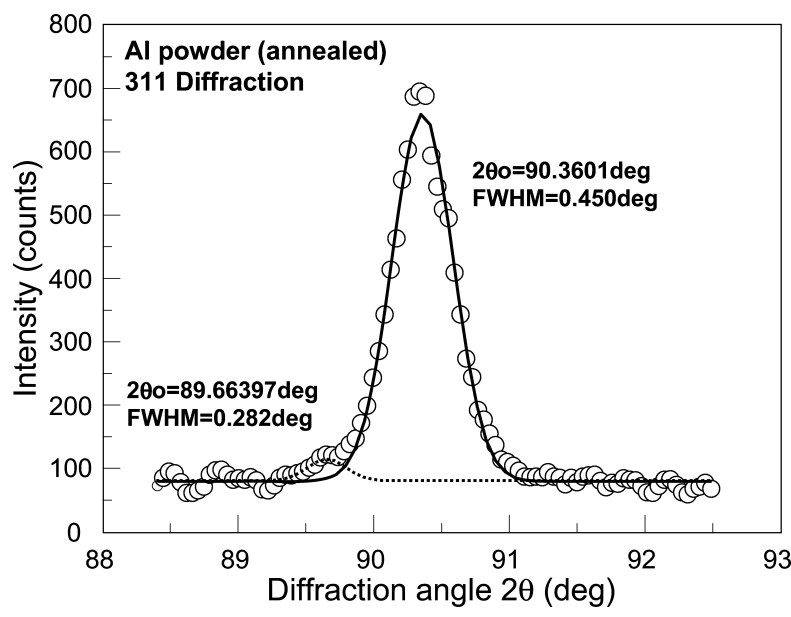

Fig. 8 Diffraction profile of annealed aluminum powder. 


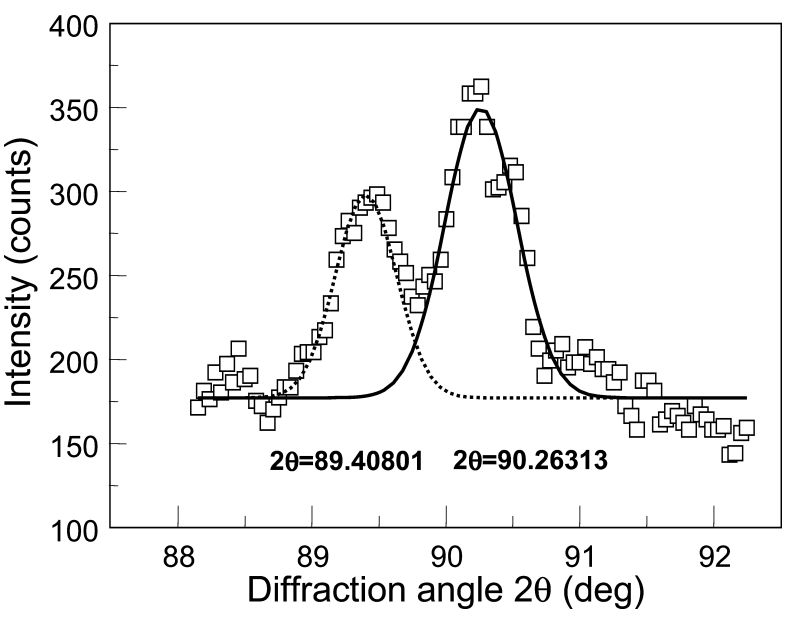

Fig. 9 Diffraction profile obtained at position \#2.

$2 \theta=89.408 \mathrm{deg}$ の回折ピークが認められる. Fig. 10 にはシ リンダ隔壁中心 $\mathrm{r}=4.1 \mathrm{~mm}$ (測定位置 \#3) の回折プロフィ ルを示す。ここではほぼ単一ピークとみなせる. Fig. 8 に 示した $2 \theta=89.408 \mathrm{deg}$ の回折ピークはシリンダ隔壁の表 面に近いほど強く現れているが，アルミニウム合金 (ADC12Z) で想定される相のいずれにも認められないも のであり，現在のところ解明できていない.

予備測定の結果からは，エンジンブロックの結晶粒径 がかなり大きいことが想定されたため，エンジンブロック を最大で $\pm 5 \mathrm{deg}$ 摇動させた。その結果得られた格子定数 と摇動角度との関係を Fig. 11 に示す. 測定位置\#1 ( $\mathrm{r}=$ $1.0 \mathrm{~mm})$ では多少変動しているが，他の 4 箇所では摇動 角度が $\pm 1.0 \mathrm{deg}$ ないし $\pm 1.5 \mathrm{deg}$ でほぼ回折ピーク角度は 安定している。これはRESA-2 を用いた予備測定の結果か らは予想されなかったことであり，RESA-1の本来の入射 ビーム強度が高いこと, あるいは, 縦収束入射コリメータ により入射ビーム強度が高くなったこと, さらには, Fig. 7 に示したように初期の予想と異なり，結晶粒径が $15 \mu \mathrm{m}$ と小さかったことが影響したものと考えられる．以下で は摇動角度 $\omega= \pm 5.0 \mathrm{deg}$ の結果を用いて議論する。

アルミニウム合金の 311 回折から得られたシリンダ隔 壁の板厚方向 r（エンジンの長手方向）に扎ける残留ひ

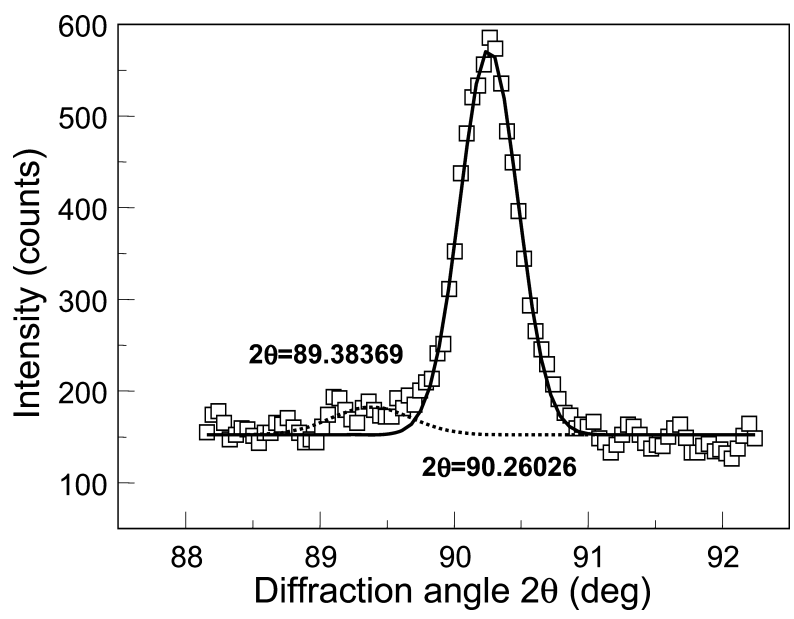

Fig. 10 Diffraction profile obtained at position \#3.

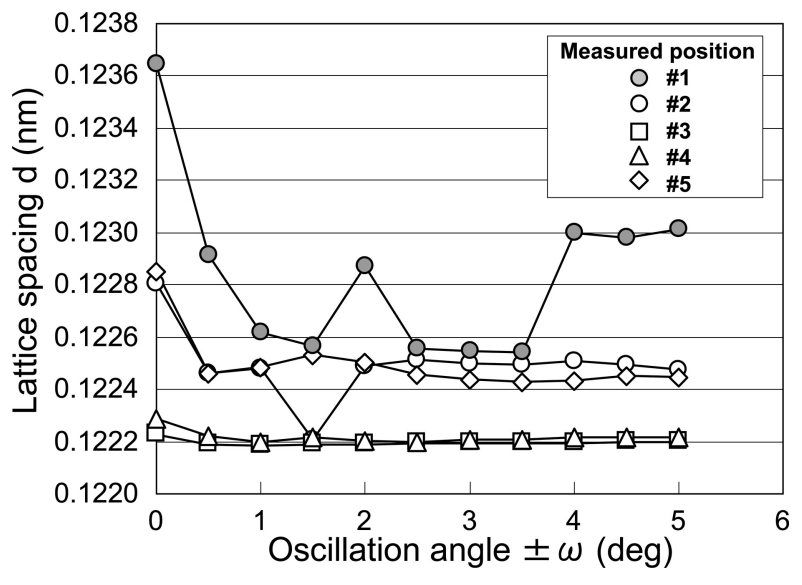

Fig. 11 Effect on oscillation angle on diffraction peak position.

ずみ分布を Fig. 12 に示す．測定のエラーバーを図中に 示したが，表面層ではアルミニウム合金の 311 回折より も不明の相の回折強度が高く，311 回折で得られたひず みの測定精度はよくない.

Fig. 13 に Fig. 12 のひずみ分布から得られたシリンダ 隔壁における残留応力分布を示す．傾向としてはいずれ の方向の残留応力も，表面層が圧縮応力で，板厚中央部 が引張応力という静水圧的な分布である．周方向応力は 板厚方向でほぼ対称の分布となっているが，シリンダ半 径方向と軸方向の応力は若干非対称である.

シリンダブロックの強度上で重要となるのは周方向応 力であるが，それは表面近傍では約 $40 \mathrm{MPa}$ の圧縮応力 で, 板厚中央部では $65 \sim 90 \mathrm{MPa}$ の引張応力である。

\section{4 考}

\section{察}

入射ビームスリットと測定試料の距離を大きくとりつ つ，入射ビーム強度を高くするために，縦方向収束ラジ アルコリメータを設計製作した。今回開発した仕様はス リット試料間距離 $\mathrm{L} 1=500 \mathrm{~mm}$ で，ゲージ位置でのビー 厶高さ $5 \mathrm{~mm}$ である. Fig. 3 と Fig. 4 に示したように， ゲージ位置での入射ビーム強度は最大となり，ビーム高さ も最小の $5 \mathrm{~mm}$ となり，設計通りの結果を得ることができ た。このように入射側に縦方向収束コリメータを設ける

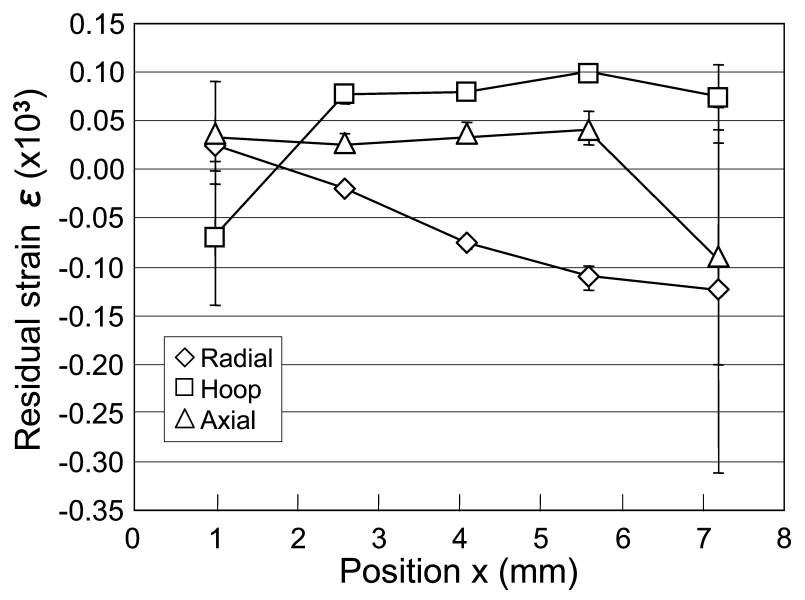

Fig. 12 Residual strain distribution in cylinder wall. 


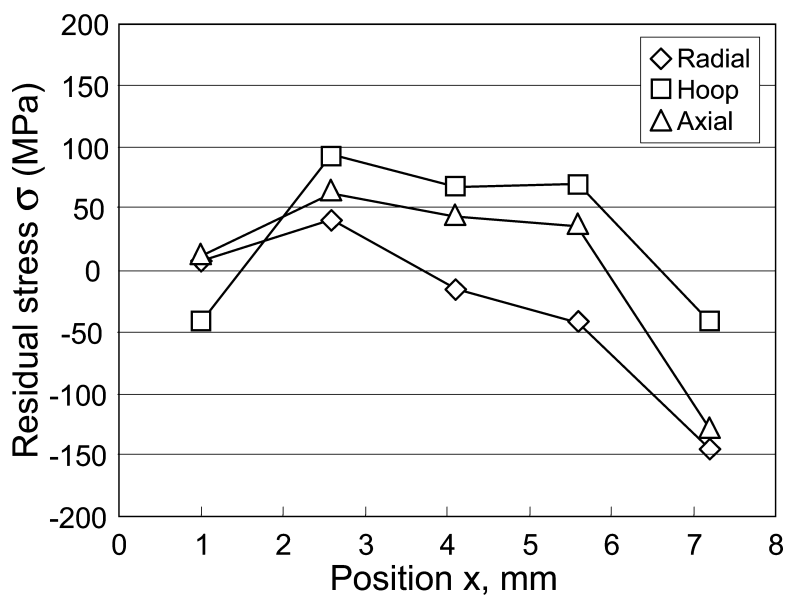

Fig. 13 Residual stress distribution in cylinder wall.

と，スリットー試料間距離を長く取ることができるので， 2 軸方向ひずみを測定するために入射ビームスリットの位 置変えが不要となり, 測定効率が向上する。 また, 入射 ビーム強度も高くなるため，ゲージ体積を小さくしたり， 測定時間を短縮できるというメリットがある，今後，ゲー ジ位置でのビーム高さを変えたコリメータを数個設計製 作する計画である。

シリンダ隔壁に抢ける残留応力の分布は, 周方向, 板 厚方向, シリンダ軸方向ともに, 表面層に扎いては圧縮 応力で, 隔壁中央部では引張応力であり, 静水圧的な分 布である．周方向応力は隔壁板厚方向で対称になるはず であるが，測定した結果は対称になっていない，これは Fig. 5 に測定状況を示したように, 入射ビームと回折ビー ムがエンジンブロック内で複雑な経路をたどるために測 定䛊差が大きかったことなどが考えられる.

周方向の残留応力は隔壁板厚方向でバランスするもの と仮定して, 補正すると, 表面では約 $70 \mathrm{MPa}$ の圧縮応 力となった.

シリンダ隔壁表面は鋳造時には中子に接しており，先 に凝固し，隔壁中央部が後から凝固する。年のため表面 層は圧縮応力となる。一方, シリンダ内面には鋼製のラ イナーが挿入されている. 外径がシリンダ内径よりも僅 かに大きいライナーをかしめる状態で挿入するため，ア ルミニゥム合金隔壁が全体として引張応力になると思わ れる。ただし，ライナーは非常に薄いために, 応力分布 への影響は小さいと思われ，残留応力の大半は鋳造工程 により導入されたものと考えられる。いずれにしても，強 度上, 重要となるシリンダ内面側の周方向の残留応力は 約 70MPa の圧縮応力と見積もられる.

上述のシリンダ表面の応力というのは, 飽くまで表面 から $\mathrm{r}=1.0 \mathrm{~mm}$ 内部のゲージ体積での平均の応力であ る. シリンダ隔壁内の応力分布は 2 次式で近似できると 仮定して, シリンダ壁表面での周方向残留応力を推定し た. その結果を Fig. 14 に示す. 灰色四角が測定された 周方向残留応力で, 2 次式で近似したものが実線である. これからシリンダ壁表面に打ける残留応力として-131〜 -142MPa が得られる. また, 図中にも示したが，平均の

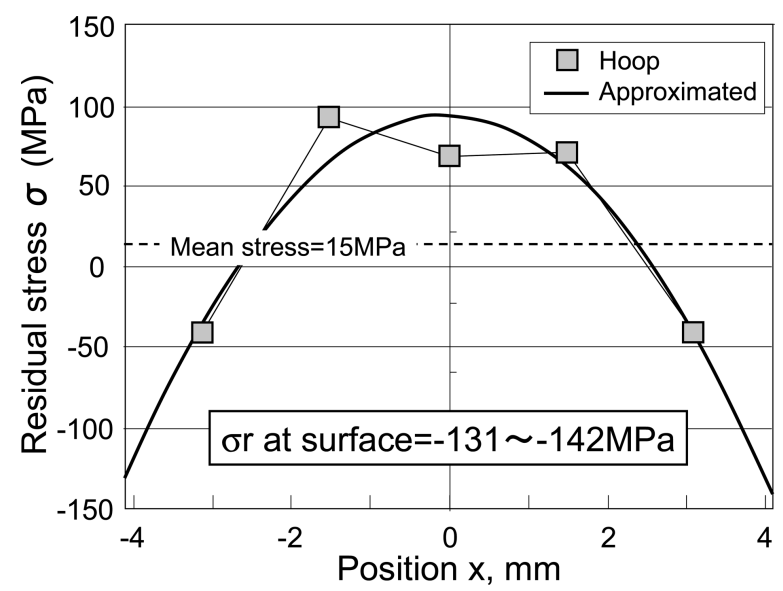

Fig. 14 Modified residual stress distribution in cylinder wall.

残留応力は $15 \mathrm{MPa}$ で非常に低いことが分かった。なお， 残留応力分布がシリンダ隔壁内に打いて板厚方向で対称 であると仮定して補正した結果では，シリンダ壁表面の 残留応力は-152MPa が得られた。 いずれにしても, シリ ンダ壁表面における残留応力は約-140MPa 程度とかなり 高い圧縮応力であり，強度上は安全側にあるといえる．

なお，測定に供したエンジンブロックは新品ではなく， 約 5 年使用されたものである。このことは, 逆に経年し たとしてもアルミニウム合金としては十分に高い圧縮残 留応力がシリンダ隔壁に保持されていることを示してお り，信頼性が高いことを示していると言える．今後可能 であれば，新品のエンジンブロックの測定を行い，経年 後の残留応力との比較を行いたいと考える.

\section{5 結}

本研究では，アルミニウム合金製のエンジンブロック シリンダ隔壁の残留応力分布を中性子により測定する技 術を確立するために, 入射ビーム側に縦方向集光ラジア ルコリメータを設計製作し，1,500cc 級エンジンに適用 した。攵の結果，以下の結論が得られた。

（1）鉛直面内集光型入射スリットは有効で，入射中性 子強度を低下させることなく，スリットーゲージ体積中 心間距離を $500 \mathrm{~mm}$ と大きくとることができる。これに より，2 軸方向のひずみを入射スリット位置を変えるこ となく, 連続で測定可能である.

(2) 全長が約 $600 \mathrm{~mm}$ の $1500 \mathrm{cc}$ 級アルミニウムエン ジンブロック中央部のシリンダ隔壁内における残留応力 を非破壊で測定できた。

（3）シリンダ隔壁表面の周方向残留応力は測定した結 果からは-70MPa と見込まれる. 周方向残留応力が板厚 内で 2 次式で近似できるものと仮定すると, シリンダ壁 表面の残留応力は約-140MPa と十分に高い圧縮応力で あると推定される。

本研究に打ける縦方向収束ラジアルコリメータの開発 に当たってはJ-PARC センターの鈴木淳市氏と篠原武尚氏 に構造設計で協力していただいた，また，製作に当たっ ては, 茨城県商工労働部の中性子関連産業応用事業のご 支援をいただいた。ここに謝意を表する。 


\section{参 考 文 献}

1) The Society for Materials Science, Japan, "Standard method for X-ray stress measurement”, Committee on X-ray Materials Strength, (2002), JSMS (in Japanese).

2 ) K. Suzuki, K. Wada, H. Matsubara, T. Shobu, M. Kawamura and K. Tanaka, "Residual stress in zirconia coating by EBPVD method”, Journal of the Society of Materials Science, Japan, Vol.56, No.7, pp.588-593 (2007).

3 ) T. Shobu, J. Mizuki, K. Suzuki, Y. Akiniwa and K. Tanaka, "Correction of surface aberration in strain scanning method with analyzer", Journal of the Society of Materials Science, Japan, Vol.55, No.1, pp.101-108 (2006).

4 ) M. Hayashi, M. Ishiwata, N. Minakawa and S. Funahashi, "Residual stress measurements in socket welded joints by neutron diffraction”, Journal of the Society of Materials Science, Japan, Vol.44, No.12, pp.1464-1469 (1995).
5 ) M. Hayashi, M. Ishiwata, Y. Morii, N. Minakawa and J. H. Root, "Residual stress distribution in carbon steel pipe welded joint measured by neutron diffraction”, Materials Science Research International, Vol.6, No.4, pp.287-294 (2000).

6) H. Suzuki and T. M. Holden, "Neutron diffraction measurements of stress in an austenitic butt weld”, Journal of Strain Analysis, Vol.41, No.8, pp.575-582 (2006).

7 ) K. Tanaka and Y. Akiniwa, "Diffraction measurements of residual macrostress and microstress using X-rays synchrotron and neutrons”, Japan Society for Mechanical Engineers International Journal, Series A, Vol.47, No.3 pp.252263 (2004) 